\title{
Acute Effects of Ambient Air Pollution on Lower Respiratory Infections in Guangzhou Children of China
}

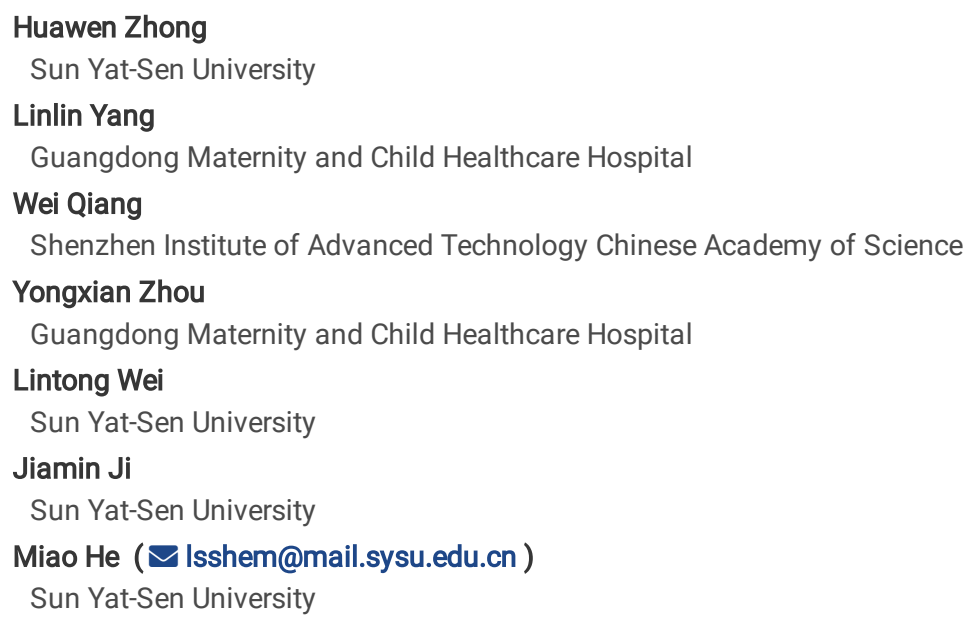

Research Article

Keywords: Ambient air pollutant, Children, Pneumonia, Pathogenic microorganisms

Posted Date: November 29th, 2021

DOI: https://doi.org/10.21203/rs.3.rs-350683/v2

License: @ (i) This work is licensed under a Creative Commons Attribution 4.0 International License. Read Full License 


\section{Abstract}

Daily concentrations of air pollution are associated with lower respiratory diseases. We investigated the short-term association of ambient air pollution with daily hospital admissions due to pneumonia among children aged 0-17 in Guangzhou city of China. Ambient air pollutants were all positively associated with children hospital admissions due to pneumonia of all ages. Significant associations were found for air pollutants except for inhalable particulate matter $(P M) \leq 10 \mu \mathrm{m}$ in aerodynamic diameter $\left(\mathrm{PM}_{10}\right)$ in children of all ages. Increments of an interquartile range (IQR) $\left(279.10 \mu \mathrm{g} / \mathrm{m}^{3} \mathrm{and}\right.$ $28.42 \mu \mathrm{g} / \mathrm{m}^{3}$, respectively) in the 7-day-average level of carbon monoxide $(\mathrm{CO})$ and nitrogen dioxide $\left(\mathrm{NO}_{2}\right)$ were associated with a $26.17 \%(95 \%$ confidence interval $(\mathrm{Cl}) 1.40 \%-56.98 \%)$ and $25.09 \%(95 \% \mathrm{Cl}$ 0.54\%-55.64\%) increase in pneumonia hospitalizations for children aged 6-17, respectively. An IQR increase in $\mathrm{CO}$ concentrations was associated with a $15.15 \%(95 \% \mathrm{Cl} 4.34 \%-27.08 \%)$ increase in pneumonia hospitalizations for children aged 1-5. Daily cases of microbial detection for pneumonia were positively associated with daily $\mathrm{NO}_{2}$ concentration. The pneumonia hospitalizations due to Mycoplasma pneumonia, Flu A virus and Flu B virus, the predominant pathogenic microorganisms detected in children aged 0-5 are apparently associated with levels of $\mathrm{PMs}, \mathrm{CO}, \mathrm{NO}_{2}$ and $\mathrm{O}_{3}$.

\section{Introduction}

Pneumonia in children refers to pulmonary inflammation in the population aged less than 18 years caused by different pathogenic or other factors. It easily occurs in all seasons, mainly in spring and winter ${ }^{[1]}$. Severe pneumonia is the major cause of death of children under 5 years old in China, in which, most of patient die of various kinds of pneumonia. Pneumonia pathogens include bacteria, virus and atypical pathogens such as Mycoplasma pneumoniae and Chlamydia pneumonia etc. The Western Pacific region had an estimated 0.11 pneumonia episodes per child-year with 61,900 pneumonia-related deaths in children less than 5 years of age in $2011^{[2]}$. Furthermore, family jam ${ }^{[3]}$ and malnutrition ${ }^{[4]}$ also result in pulmonary inflammation. Time series analysis shows that pneumonia hospitalizations in children are associated with ambient air pollution level ${ }^{[5-8]}$. A child's respiratory system is susceptible to the adverse health effects of air pollution due to lower immunity.

The association between air pollution and hospitalization for acute respiratory infection (ARI) has been investigated worldwide ${ }^{[9]}$. Increased concentrations of nitrogen dioxide $\left(\mathrm{NO}_{2}\right)$ and sulfur dioxide $\left(\mathrm{SO}_{2}\right)$ were associated with increased admissions of pneumonia in Vietnamese children in the dry season (November-April), with excess risks of $8.50 \%$ (95\% confidence interval (Cl) $0.80-16.79)$ and $5.85 \%$ (95\% Cl 0.44-11.55), respectively. Daily concentrations of particulate matter $(\mathrm{PM}) \leq 10 \mu \mathrm{m}$ in aerodynamic diameter $\left(\mathrm{PM}_{10}\right)$ could be positively associated with increased pneumonia admissions in children in the dry season. Negative associations between air pollutants and pneumonia admissions in children were observed in the rainy season (May-October) in Vietnam ${ }^{[10]}$. Daily concentrations of $\mathrm{PM}_{10}$ and ozone $\left(\mathrm{O}_{3}\right)$ were strongly associated with hospitalizations of lower respiratory tract infection in children aged 2-5 ${ }^{[11]}$. In the meantime, a report from Malaysia pointed out that increased acute lower respiratory tract infection admissions in children under 18 were associated with low rainfall but not $\mathrm{PM}_{10}$ nor air pollutant index ${ }^{[12]}$.

The air quality is getting worse in the progress of industrialization and urbanization process in China, which increases the disease burden of respiratory system ${ }^{[13]}$. The air pollutants are acutely and chronically associated with number of hospitalization, morbidity, mortality, clinical symptoms and pulmonary function change for various diseases in China ${ }^{[14]}$. If the total suspended particles (TSP) in the atmosphere reached to $184 \mu \mathrm{g} / \mathrm{m}^{3}$ in Northern China, life time of local people would be reduced by 5.5 years ${ }^{[15]}$. Daily concentration of $P M \leq 2.5 \mu m$ in aerodynamic diameter $\left(\mathrm{PM}_{2.5}\right)$ was associated with all-cause mortality in Shanghai city (risk ratio (RR) 1.0068 , for time lag0, 95\% Cl 1.0013-1.0123) ${ }^{[16]}$. $\mathrm{PM}_{2.5}$ concentration was positively associated with daily hospital admissions for disease of respiratory system in Ji'nan, a provincial capital city in Northern China ${ }^{[17]}$. Elevated PM $_{2.5}$ and PM $_{10}$ were significantly associated with increased emergency department (ED) visits for pneumonia, respiratory tract infection (RTI) and coronary heart disease at both lag0 and lag0-3 in Guangzhou city. A $10 \mu \mathrm{g} / \mathrm{m}^{3}$ increment of $\mathrm{PM}_{2.5-10}$ (PMc) was estimated to increase ED visits for pneumonia by $6.32 \%$ (95\% Cl $4.19 \%-8.49 \%)$ and for RTI by $4.72 \%$ (95\% Cl 3.81\%-5.63\%), respectively. PMc showed stronger cumulative effects on asthma in children than elderly [18]. Daily concentration of $\mathrm{SO}_{2}$ was apparently associated with respiratory mortality in Xi'an (RR $\left.1.4200,95 \% \mathrm{Cl} 0.8270-2.8540\right)$, a provincial capital city in Western China ${ }^{[19]}$. The air pollutant levels in Wuhan city of Central China and Lanzhou city of Western China were obviously and positively correlated to pneumonia hospitalizations in children ${ }^{[20]}$.

Guangzhou is the first-tier city in Southern China, covering 7, 434.4 $\mathrm{km}^{2}$. Guangzhou had about 14. 90 million inhabitants in 2018 with an average population density of about 2,005 people/ $\mathrm{km}^{2}$. Children accounted for $19.11 \%$ of the total population here ${ }^{\text {[21] }}$. The concrete population density and geography location are shown in the additional file 1 . The air was seriously polluted by vehicle tail gas, industrial pollution, raised dust of construction sites in Guangzhou city. The proportion of days with Air Quality Index (AQI) levels greater than 100 (unhealthy level to sensitive group) ranged from $4.66 \%$ to $41.54 \%$ of total monitoring days between 2013 and 2018, according to 2018 year-book of Air Quality in Guangzhou issued by the National Bureau of Statistics of China ${ }^{[22]}$. The risk assessment of ambient air pollutants on the daily hospital admissions of pneumonia in Guangzhou children remains sparse. Therefore, this study investigated the short-term effects of exposure to ambient air pollution on hospital admissions due to pneumonia in Guangzhou children under 17 years old. We also explored the impact of age, gender, season and pathogenic microorganism detected results on these associations.

\section{Methods}




\section{Data source}

Data of ambient air pollutants used in this study came from the Guangzhou Municipal Air Quality Real-time Release Platform of the Chinese Environmental Monitoring Center (http://210.72.1.33:8023/gzaqi_new/RealTimeDate.html) ${ }^{[36]}$. The hourly means of air pollutants combined the data recorded from eleven fixed monitoring stations, which are Guangya Middle School station (113² $\left.23^{\prime} 5^{\prime \prime E}, 23^{\circ} 14^{\prime} 22^{\prime \prime} \mathrm{N}\right)$, Guangzhou No. 5 Middle School station $\left(113^{\circ} 26^{\prime} 1{ }^{\prime \prime} \mathrm{E}, 23^{\circ} 10^{\prime} 5^{\prime \prime} \mathrm{N}\right)$, Tianhe Vocational and Youth station $\left(113^{\circ} 33^{\prime} 33^{\prime \prime} \mathrm{E}, 23^{\circ} 13^{\prime} 42^{\prime \prime} \mathrm{N}\right)$, Guangdong Business School station (113 $34^{\prime} 8^{\prime \prime} \mathrm{E}$,

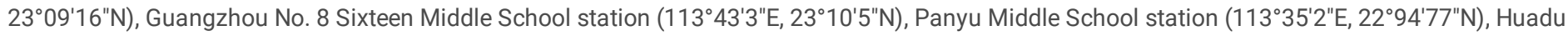
Teachers' station $\left(113^{\circ} 21^{\prime} 5^{\prime \prime} \mathrm{E}, 23^{\circ} 39^{\prime} 17^{\prime \prime} \mathrm{N}\right)$, Guangzhou station $\left(113^{\circ} 26^{\prime} \mathrm{E}, 23^{\circ} 27^{\prime} 83^{\prime \prime} \mathrm{N}\right)$, Jiulong Zhenlong station (113 $\left.56^{\prime} 8^{\prime \prime} \mathrm{E}, 2^{\circ} 27^{\prime} 83^{\prime \prime} \mathrm{N}\right)$, Wuhu station $\left(113^{\circ} 28^{\prime} 1{ }^{\prime \prime} \mathrm{E}, 23^{\circ} 15^{\prime} 69^{\prime \prime} \mathrm{N}\right)$ and Maofengshan Forest Park station $\left(113^{\circ} 58^{\prime} 9^{\prime \prime} \mathrm{E}, 23^{\circ} 55^{\prime} 38^{\prime \prime} \mathrm{N}\right)$. Data were averaged by station and calendar day to provide 24-h means of $\mathrm{PM}_{2.5}, \mathrm{PM}_{10}, \mathrm{SO}_{2}, \mathrm{NO}_{2}, \mathrm{O}_{3}$ and carbon monoxide (CO). The missing data was estimated by linear interpolation, and a total of 1,707 days from October 28, 2013 to June 30, 2018 of air quality data was obtained.

Data of meteorological factors were collected for the same period from Reliable Prognosis website (http://rp5.ru/docs/about/cn) [37], which provides every three hours recording of temperature (in ${ }^{\circ} \mathrm{C}$ ), relative humidity (in percent), wind speed (in $\mathrm{m} / \mathrm{s}$ ), rainfall (in $\mathrm{mm}$ ), atmospheric pressure (in mmHg) and horizontal visibility (in $\mathrm{km}$ ) at the Guangzhou Airport Meteorological station $\left(113^{\circ} 30^{\prime} 97^{\prime \prime} \mathrm{E}, 23^{\circ} 39^{\prime} 29^{\prime \prime} \mathrm{N}\right.$ ). Data were averaged by calendar day to provide 24-h means of these meteorological data.

Children hospital admission records of pneumonia (International Classification Diseases 11th revision (ICD11) code CA40) sourced from the Guangdong Maternal and Child Healthcare Hospital (GDMCHH), covering a total of 17, 149 anonymous cases from October 28, 2013 to June 30,2018 . The records include clinical diagnosis, admission number, gender, age and pathogenic microorganism test results of sputum cultivation (including Chlamydia pneumoniae, Haemophilus, Mycoplasma pneumoniae, Influenza A virus, Influenza B virus, Parainfluenza virus, Adenovirus and Respiratory syncytial virus). GDMCHH is a large-scale tertiary hospital with healthcare, medical, educating, scientific research, training and technical guidance. It is the educating hospital of eight universities including Sun Yat-Sen University, while it also establishes cooperation with Boston Children's Hospital of Harvard Medical School. Having two hospital districts with 1,500 beds and one branch of the Guangdong Cord Blood Bank. GDMCHH is one of the best maternal and child healthcare hospital in Southern China. Its clinical diagnosis records greatly reflect the children incidence of pneumonia in Guangzhou city. This study was conducted on October 1st, 2019.

All of the children patient records were anonymized and de-identified, the study underwent an ethical review by the ethical committee of GDMCHH (Approval number: 201901121, September 2019). All research were performed following the approved guidelines. The study was obtained the informed consent of all participants and their legal guardians.

\section{Data analysis}

To study the association between ambient air pollution and daily counts of hospital admissions for pneumonia, we used the semi-parametric generalized additive quasi-Poisson regression models with a log-link function and adjustment for over-dispersion, adjusting for potential confounders. Thin plate spline functions were used to capture the time trends and seasonal variations. The potential confounders were integrated into the models which including daily mean temperature, relative humidity, wind speed, rainfall, day of the week (DOW) and holidays. DOW was treated as a categorical variable with values ranging from 1 (Sunday) to 7 (Saturday). We had adjusted for meteorological factors averaged over the same day and the day before (lag 0-1) and over the five days preceding the period (lag 2-6) and the interaction terms between them. Smoothing spline functions were used to non-parametric smooth of the meteorological data. The time nonlinear independent variables (time=1-1707) in the time series data were fitted and the most suitable smooth spline function degree of freedom was selected by the Generalized Cross-Validation (GCV). When the basic model was established, the air pollutant concentrations were added into the model to be the linear variables, we computed the associations between the two days moving average (lag 0-1), three-day moving average (lag 0-2), and seven-day moving average (lag 0-6) air pollutant concentrations and children hospital admissions. To facilitate comparing the effects of air pollutants, results were reported as RRs of hospital admissions with $95 \% \mathrm{Cl}$ for the one interquartile range (IQR) increment in the level of the respective pollutant variable. Meanwhile, analyses were performed for gender, ages (infants, children aged 1-5, aged 6-17 and children of all ages 0-17) and seasons (spring: March - May, summer: June - August, fall: September - November, winter: December - February). Statistical significance was defined as two-tailed $p$-value $<0.05$.

We also built two-pollutant models combining the pollutants which including $\mathrm{PM}_{10}, \mathrm{PM}_{2.5}, \mathrm{SO}_{2}, \mathrm{NO}_{2}, \mathrm{CO}$ and $\mathrm{O}_{3}$. Variance inflation factor (VIF) was used to evaluate the multicollinearity in these models. All pairs of pollutants had VIF-values maximum of 7.6 that is below the threshold of 10 indicating the strong multicollinearity ${ }^{[38]}$.

However, investigations of associations among meteorological factors, air pollutants and the clinical pathogenic microorganism inspection results for pneumonia in children aged 0-17 in China remain sparse. Because of too many zero-values for the detected results of sputum microbial cultivation which obeyed the zero inflation Poisson distribution, these data were not applicable to the ordinary Poisson regression model. In order to find interpretively independent variables as well as improve the explanatory power and accuracy of the models' prediction, we used Lasso regression model to explore the associations between ambient air pollutants and daily detected results of sputum microbial cultivation after considering the effects of meteorological factors, DOW, holidays and seasons. The initial Lasso regression model was derived for the daily cases of microbial detection for pneumonia, and air pollutants (lag 0-6) as well as meteorological factors. The cross-validation method was used to select the Lambda with the least 
average error to optimize the model. Finally, we calculated the root mean-square error (RMSE) which indicated the quality of the models. All statistical analyses were completed using the "mgcv", "spline" and "glmnet” packages of $R$ language (version 3.5.3, http://www.r-project.org).

\section{Results}

Descriptive statistics for daily hospital admissions and detected results of sputum cultivation present in Table 1, while Table 2 presents descriptive statistics for daily air pollutant concentrations and meteorological variables. The investigation contained 17,149 hospital admissions for pneumonia (i.e., about average 10.04 cases a day). In daily hospital admissions, the counts of male were about 1.8 times than that of female. Out of all hospital admissions, infants, children aged $1-5$ years and $6-17$ years accounted for $67.30 \%, 27.70 \%$ and $5.03 \%$, respectively. The daily hospital admissions were maximum in spring. The microbiological detection items for children hospitalizations with pneumonia included Chlamydia pneumoniae, Haemophilus, Mycoplasma pneumoniae, Influenza A virus, Influenza B virus, Parainfluenza virus, Adenovirus and Respiratory syncytial virus. The daily hospital admissions accounted $46.70 \%$ for pulmonary Mycoplasma pneumoniae, $21.60 \%$ and $9.98 \%$ for Flu $A$ and $B$ virus respectively, but $1.99 \%$ for Haemophilus. There were seasonal preferences for daily hospital admission counts due to different pathogenic microorganisms.

Daily mean concentration of $\mathrm{PM}_{2.5}$ was $39.80 \mu \mathrm{g} / \mathrm{m}^{3}$, which exceeded the 24 -h mean concentration of fine particles $\left(25 \mu \mathrm{g} / \mathrm{m}^{3}\right) \mathrm{by} 37.19 \%$ set in the World Health Organization (WHO) guidelines for air quality. Daily mean concentration of $\mathrm{PM}_{10}$ was $60.80 \mu \mathrm{g} / \mathrm{m}^{3}$, which exceeded the $24-\mathrm{h}$ mean concentration of inhalable particles $\left(50 \mu \mathrm{g} / \mathrm{m}^{3}\right)$ by $17.76 \%$ set in $\mathrm{WHO}$ guidelines for air quality. Daily mean concentrations of $\mathrm{CO} \mathrm{NO}_{2}, \mathrm{O}_{3}$ and $\mathrm{SO}_{2}$ were $935.00 \mu \mathrm{g} / \mathrm{m}^{3}, 37.30 \mu \mathrm{g} / \mathrm{m}^{3}, 46.90 \mu \mathrm{g} / \mathrm{m}^{3}$ and $12.90 \mu \mathrm{g} / \mathrm{m}^{3}$, respectively, which were all lower than WHO standards. Daily concentrations of air pollutants were highest in winter and lowest in summer, except for $\mathrm{O}_{3}$. While, daily concentration of $\mathrm{O}_{3}$ was highest in autumn and lowest in winter. It indicated that daily mean concentrations of air pollutants were associated with daily mean temperature, relative humidity and rainfall. Daily means of air pollutants were significantly correlated with each other. Daily means of $\mathrm{PM}_{2.5}$ was strongly correlated with daily means of $\mathrm{PM}_{10}(\mathrm{Spearman}$ rank correlation coefficient, $r=0.97)$. Both daily means of $\mathrm{PM}_{2.5}$ and $\mathrm{PM}_{10}$ were correlated to daily means of $\mathrm{SO}_{2}, \mathrm{NO}_{2}$ and $\mathrm{CO}(0.50 \leq|r| \leq 0.80)$. And as temperature decreased, the correlation coefficients between daily means of $\mathrm{SO}_{2}$ and $\mathrm{PM}_{2.5}$ or $\mathrm{PM}_{10}$ gradually increased. Daily means of $\mathrm{O}_{3}$ was remarkably correlated to daily means of $\mathrm{PM}_{2.5}$ and $\mathrm{PM}_{10}$ in summer and autumn $(0.50 \leq|\lambda| \leq 0.80)$ (see additional file 2). Daily mean temperature, relative humidity and rainfall in Guangzhou city were $21.70^{\circ} \mathrm{C}, 78.00 \%$ and $6.70 \mathrm{~mm}$, respectively.

The RRs of hospital admissions for pneumonia per IQR of the seven-day (lag 0-6) mean concentrations of the pollutants present in Table 3. Daily hospital admissions for pneumonia were positively associated with all pollutants for children of all ages. Statistically significant associations were observed for all pollutants except for $\mathrm{PM}_{10}$ in children aged 0-17 years. The RRs were statistically significant for $\mathrm{PM}_{2.5}$ in infants, $\mathrm{CO}$ in children aged 1-5 and 6-17 years, while for $\mathrm{SO}_{2}, \mathrm{NO}_{2}$ and $\mathrm{O}_{3}$ in children aged 6-17 years. The strongest effect estimation was observed for $\mathrm{CO}(\mathrm{RR}=1.26,95 \% \mathrm{Cl} 1.01-1.57)$ in children aged 6-17 years. The RRs of 1.15 (95\% $\mathrm{Cl} 1.04-1.27)$ and 1.06 (95\% $\mathrm{Cl}$ 0.95-1.18) corresponded to about one additional case for short term increments in $\mathrm{CO}$ and $\mathrm{NO}_{2}$ respectively of one IQR (i.e. $279.10 \mu \mathrm{g} / \mathrm{m}^{3}, 28.42 \mu \mathrm{g} / \mathrm{m}^{3}$, respectively) in children aged 1-5 years.

The RRs for pneumonia hospitalization were higher among children aged 1-5 and 6-17 years as compared to infants, except for PM 2.5 . For example, the RR for an IQR increase in CO was highest among children aged 6-17 years and lower in infants (RR=0.97, 95\% Cl 0.89-1.05). Similar modes were found for lag 0, lag 0-1 and lag 0-2 (see additional file 3, additional file 4 and additional file 5). The RRs per IQR ranged from 0.97 to 1.05 for lag 0 , from 0.99 to 1.05 for lag $0-1$, from 1.00 to 1.06 for lag $0-3$ and from 0.95 to 1.06 for lag 0-6 means for all pollutants in children under 17 years.

The season-specific RRs of pneumonia hospitalizations per IQR increase in the seven-day (lag 0-6) moving average concentrations of ambient air pollutants present in Fig 1. Daily hospital admissions for pneumonia were positively associated with $\mathrm{PM}_{2.5}$ and $\mathrm{PM}_{10}$ in gender and all age groups. Daily hospital admissions for pneumonia were statistically significant for all pollutants in children aged 6-17 years, except for $\mathrm{PM}_{2.5}$ and $\mathrm{PM}_{10}$. Associations with pneumonia hospitalizations were significantly different for pollutants in different seasons. For example, the $\mathrm{RR}$ for an IQR increase in $\mathrm{SO}_{2}$ was higher among children aged 6-17 years in the winter $(\mathrm{RR}=1.43,95 \% \mathrm{Cl} 1.09-1.87)$. The $\mathrm{RR}$ per IQR for $\mathrm{NO}_{2}$ was higher in the summer $(\mathrm{RR}=3.99,95 \% \mathrm{Cl}$ 1.42-11.26). And the RR per IQR for $\mathrm{CO}$ was higher in the spring (RR=1.60, 95\% $\mathrm{Cl} 1.08-2.37)$. Similar modes were found for lag 0 , lag $0-1$ and lag $0-2$ (see additional file 3 , additional file 4 and additional file 5).

Two-pollutant models presented in Fig 2 and additional file 6. Estimates for $\mathrm{NO}_{2}$ were the largest (per IQR) after inclusion of PM 2.5 and PM 10 , but stable after inclusion of $\mathrm{SO}_{2}$ and $\mathrm{CO}$. Effects of $\mathrm{CO}$ were higher after inclusion of $\mathrm{PM}_{2.5}$ and $\mathrm{PM}_{10}$, but stable after inclusion of other pollutants. In contrast, effects of $\mathrm{O}_{3}$ all dropped or lost statistical significance after inclusion of $\mathrm{PM}_{2.5}, \mathrm{PM}_{10}, \mathrm{SO}_{2}$ or $\mathrm{NO}_{2}$ in children aged 6-17 years. Results for pneumonia and $\mathrm{O}_{3}$ were also insensitive to the inclusion of other pollutants in other age groups (see additional file 6).

The season-specific two-pollutant models of $\mathrm{NO}_{2}$ and $\mathrm{CO}$ for age groups presented in Fig 3. Daily hospital admissions for pneumonia were statistically significant difference in different seasons. Effects of $\mathrm{NO}_{2}$ were higher in summer and autumn after inclusion of $\mathrm{PM}_{2.5}, \mathrm{PM}_{10}, \mathrm{SO}_{2}, \mathrm{CO}$ and $\mathrm{O}_{3}$.

Furthermore, estimates for $\mathrm{NO}_{2}$ were the larger with the increase of age. Estimates for $\mathrm{CO}$ were somewhat less sensitive to seasonal variation. Effects of $\mathrm{CO}$ were statistically significant among children under 5 years old in summer. But, effects of CO were significantly higher in spring after inclusion of $\mathrm{PM}_{2.5}, \mathrm{PM}_{10}, \mathrm{SO}_{2}$ or $\mathrm{NO}_{2}$ in children aged 6-17 years. 
The descriptive statistics of the clinical pathogenic microorganism inspection results for pneumonia presents in additional file 7. The detected cases of pulmonary Mycoplasma pneumoniae were the most predominant. The positive rate of detection for female was higher than that for male, and the positive rate was the largest in the age group 1-5 year. The positive rate minimized in winter for all kinds of pathogenic microorganisms, except that for Chlamydia pneumoniae and Hemophilus. The cases of microbial detection due to pneumonia increased initially, but decreased during 2014 to 2018.

The Lasso regression model was derived for the daily cases of microbial detection due to pneumonia and air pollutants (lag 0-6), combined with meteorological factors. Regression coefficients (RCs) and root mean square errors (RMSEs) of models present in Table 4. $\mathrm{RCs}$ of $\mathrm{NO}_{2}$ were always positive which indicated that $\mathrm{NO}_{2}$ had positive effects on the daily cases of microbial detection for pneumonia. $\mathrm{RCs}$ of $\mathrm{O}_{3}$ were almost positive except for Flu B virus, Chlamydia pneumonia and Adenovirus. While RCs of $\mathrm{SO}_{2}$ were almost negative, except for Adenovirus, which indicated that $\mathrm{SO}_{2}$ had negative effects on the daily cases of microbial detection. Detailed estimates present in additional file 8 and additional file 9 . RCs of $\mathrm{O}_{3}, \mathrm{PM}_{2.5}$ and $\mathrm{PM}_{10}$ were mainly positive for children less than 5 years-old. $\mathrm{RCs}$ of $\mathrm{SO}_{2}, \mathrm{NO}_{2}$ and $\mathrm{CO}$ were mainly positive for children aged 6-17 years-old (see additional file 10).

\section{Discussion}

We finished a time-series larger population-based study on the acute effects of ambient air pollution on children's health in Guangzhou city of China. Overall, associations with pneumonia hospital admissions were strongest for CO and $\mathrm{NO}_{2}$. Increments of an IQR $\left(279.10 \mu \mathrm{g} / \mathrm{m}^{3}\right.$ and $28.42 \mu \mathrm{g} / \mathrm{m}^{3}$ respectively) in the 7-day-average level of $\mathrm{CO}$ and $\mathrm{NO}_{2}$ were associated with a $26.17 \%(95 \% \mathrm{Cl} 1.40 \%-56.98 \%)$ and $25.09 \%(95 \% \mathrm{Cl} 0.54 \%-55.64 \%)$ increase in pneumonia hospitalizations for children aged 6-17, respectively. An IQR increase in CO concentrations $\left(279.10 \mu \mathrm{g} / \mathrm{m}^{3}\right)$ was associated with a $15.15 \%$ $(95 \% \mathrm{Cl} 4.34 \%-27.08 \%)$ increase in pneumonia hospitalizations for children aged 1-5. These results are basically consistent with the previous conclusions which showing children hospital admissions for ARI associated with markers of primary traffic pollutants such as $\mathrm{CO}$ or $\mathrm{NO}_{2}{ }^{[23]}$.

In this study, parts of ambient air pollutions levels were relatively higher than WHO standards, especially in winter. During 2013 and 2018 , daily mean $\mathrm{PM}_{2.5}$ levels ranged from $4.61 \mu \mathrm{g} / \mathrm{m}^{3}$ to $155.00 \mu \mathrm{g} / \mathrm{m}^{3}$ which exceeded the WHO guideline value (24-h mean is $25 \mu \mathrm{g} / \mathrm{m}^{3}$ ) on $1184 \mathrm{days}(69.36 \%)$, while daily mean $\mathrm{PM}_{10}$ levels ranged from $9.96 \mu \mathrm{g} / \mathrm{m}^{3}$ to $208.29 \mu \mathrm{g} / \mathrm{m}^{3}$ which exceeded recommended levels on 931 days (54.54\%). Daily mean CO levels ranged from $479.30 \mu \mathrm{g} / \mathrm{m}^{3}$ to $2610.00 \mu \mathrm{g} / \mathrm{m}^{3}$ which exceeded the WHO guideline value (24-h mean is $2000 \mu \mathrm{g} / \mathrm{m}^{3}$ ) on 5 days, daily mean $\mathrm{NO}_{2}$ levels

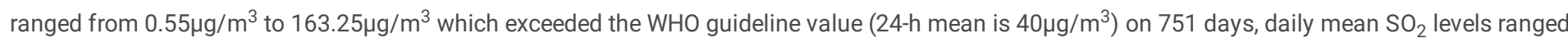
from $2.00 \mu \mathrm{g} / \mathrm{m}^{3}$ to $53.00 \mu \mathrm{g} / \mathrm{m}^{3}$ which exceeded the WHO guideline value (24-h mean is $20 \mu \mathrm{g} / \mathrm{m}^{3}$ ) on 190 days, and daily mean $\mathrm{O}_{3}$ levels ranged from $3.46 \mu \mathrm{g} / \mathrm{m}^{3}$ to $139.21 \mu \mathrm{g} / \mathrm{m}^{3}$ which exceeded the WHO guideline value (8-h mean is $100 \mu \mathrm{g} / \mathrm{m}^{3}$ ) on 59 days.

Lots of epidemiological and clinical studies indicated that ambient particulate matter (PM) in air pollution was strongly associated with increased

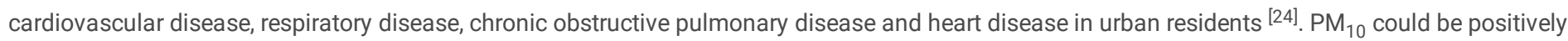
associated with increased pneumonia admissions in children in the dry season ${ }^{[10]}$. Daily mean $\mathrm{PM}_{10}$ levels were associated with prolonged

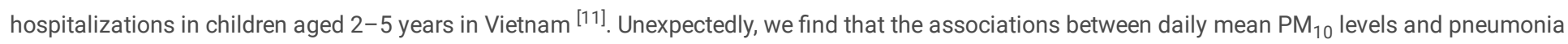
hospitalizations of children were not statistically significant in all age groups. Although, a study showed positive associations between $\mathrm{ARI}$ and both $\mathrm{NO}_{2}$ and $\mathrm{PM}_{10}$ during the dry season 2003-2005 ${ }^{[25]}$, but the results were not statistically significant given the rather short series and limited statistical power

[26]. Another report pointed out that increased acute lower respiratory tract infection admissions in children under 18 were associated with low rainfall but not $\mathrm{PM}_{10}$ nor air pollutant index ${ }^{[12]}$. So, why are the effects of $\mathrm{PM}_{10}$ completely different in different regions? Is it possible that the effect of $\mathrm{PM} \mathrm{I}_{10}$ is mainly related to climate factor, immunity and age? Sure, the differences of the effect of $\mathrm{PM}_{10}$ may also be determined by genetic predisposition. We interestingly find that air pollutants might exacerbate genetic variations associated with asthma, including GLUTATHIONE-S-TRANSFERASE M1 (GSTM1) and GLUTATHIONE-S-TRANSFERASE P1 (GSTP1) gene. Among them, GSTP1 modified the delayed effects of PM 10 and Consistent with previous studies, early living in polluted atmospheric can damage lung function on an average of 24-h for three days, and enhanced the lung respiratory function of carriers. Individuals carrying G allele could reduce the adverse effects of air pollutant in children of South Africa [27]. The gene expression level of white blood cells in Ostrava area polluted by high PM concentration had been measured. It was found that the cellular immune response pathway was affected by higher PM concentration. The expression of APURINIC/APYRIMIDINIC ENDONUCLEASE (APEX), ATAXIA-TELANGIECTASIA MUTATED (ATM), FAS CELL SURFACE DEATH RECEPTOR (FAS), GLUTATHIONE S-TRANSFERASE MU1 (GSTM1), INTERLEUKIN1 BETA (IL $1 B$ ) and RAD21 HOMOLOG (Schizosaccharomyces pombe) (RAD21) decreased significantly in Ostrava subjects, and the pathways related to neurodegenerative diseases were significantly correlated with $\mathrm{PM}_{2.5}$ exposure in Prague subjects of the Czech Republic ${ }^{[28]}$. In addition, there have been relatively few researchers studied on the gene-PM exposure interactions, and most have done on a small number of loci for genetic polymorphisms. The possible underlying molecular mechanisms for PM exposure induced increases of acute lower respiratory infections in children remain the mystery.

About $95 \%$ of children in this study population are under 5 years of age. And a larger proportion (e.g. $67.31 \%$ ) of children are infants. Hence, our results mainly reflect the effects of air pollutants in children under 5 years of age. Generally, the tertiary general hospital has a Pediatric Department in China. But hospital beds for children and the numbers of pediatric doctors are limited almost in all hospitals. Guangzhou is a super city with a population of more than 10 million. Therefore, most children with conditions requiring hospitalization are likely admitted to GDMCHH. Normally, GDMCHH is the most crowded specialist children's hospital in Guangzhou city, and children under 5 years of age are prioritized. And older children are preferably transferred to 
other local hospitals. Our results showed that the RR was statistically significant only for $\mathrm{PM}_{2.5}$ in infants $(\mathrm{RR}=0.90,95 \% \mathrm{Cl} 0.82-0.99)$. And a study findings suggested that parental exposure to $\mathrm{PM}_{2.5}$ could increase infant mortality differently by the timing of exposure and gender, which suggested a relation to fetal development in South Korea ${ }^{[29]}$. Zwozdziak et al. reported a decrease in lung function parameters with increasing exposure of indoor $\mathrm{PM}_{1}$ in school children ${ }^{[30]}$. This may be an indication that smaller size PMs induce stronger inflammatory responses, particularly the ultrafine particles that can penetrate deeply into lung alveoli or be transported to other organs ${ }^{[31,32]}$. These results also suggested that high smaller size PMs exposures might adversely influence both development of the innate immune system and development of lung function of infants. Hence, to protect infancy vulnerability of the rapid lung and immune system development from high levels of air pollution exposure is very important during the early months of life.

Our results demonstrated that the association of $\mathrm{CO}$ with hospital admissions due to pneumonia reached statistical significance in children aged $1-5$ (RR $=1.15,95 \% \mathrm{Cl} 1.04-1.27)$. And the RR per IQR for $\mathrm{CO}$ was higher in the spring (RR=1.60,95\% $\mathrm{Cl} 1.08-2.37)$. Estimates for CO were statistically significant among children aged 1-5 years in summer. While there was a diametrically opposite conclusion for $\mathrm{CO}$ in Hanoi, Vietnam ${ }^{[33]}$. How to explain this contradiction is a vexed one. Although, daily mean CO levels just exceeded the WHO guideline value on 5 days in Guangzhou during October 28,2013 to June 30,2018 . But, effects of $\mathrm{CO}$ were significantly higher in spring after inclusion of $\mathrm{PM}_{2.5}, \mathrm{PM}_{10}, \mathrm{SO}_{2}$ or $\mathrm{NO}_{2}$ in children aged 6-17 years.

We find that associations between air pollutants $\left(\mathrm{CO}, \mathrm{SO}_{2}, \mathrm{NO}_{2}\right.$ and $\left.\mathrm{O}_{3}\right)$ and pneumonia hospitalizations of children aged 6-17 years were statistically significant in Guangzhou city. Generally, Guangzhou children living in a super city should spend more time for going to schools and coming back home, the primary traffic pollutants concentrations such as $\mathrm{PMs}, \mathrm{CO}$ or $\mathrm{NO}_{2}$ were the highest during that time. No doubt the timing of air pollutants exposure increased. An investigation showed that acute lower respiratory infection admissions among children under 5 years of age were generally positively associated with ambient levels of $\mathrm{PM}_{10}, \mathrm{NO}_{2}$, and $\mathrm{SO}_{2}$ during the dry season, but not the rainy season, and negative results in the rainy season could be driven by residual confounding present from May to October in $\mathrm{Ho}$ Chi Minh City, Vietnam ${ }^{[10]}$. Daily concentration of $\mathrm{SO}_{2}$ was apparently associated with respiratory mortality in Xi'an city ${ }^{[19]}$. Daily concentrations of $\mathrm{CO}, \mathrm{NO}_{2}, \mathrm{SO}_{2}$, and $\mathrm{PM}_{10}$ were significantly associated with increased risk of both cardiovascular and respiratory hospital admissions, whereas $\mathrm{O}_{3}$ was associated with only respiratory hospital admission [33,34]. The observed seasonal difference in hospital admissions is larger than what one expects based on the difference in air pollution alone. The latter is though only one out of many determinants of hospital admissions.

The results of two pollutant models are presented in Fig 2 and additional file 6 . Basically, two-pollutant models could be used to evaluate the possible roles of single pollutants. Pneumonia related estimates for $\mathrm{NO}_{2}$ were higher after inclusion of $\mathrm{PM}_{2.5}$ and $\mathrm{PM}_{10}$ in summer and autumn, but stable after inclusion of $\mathrm{SO}_{2}$ and $\mathrm{CO}$. Estimates for $\mathrm{CO}$ were statistically significant among children aged 1-5 years in summer. The two-pollutant models revealed consistent patterns across all outcomes luckily as shown in additional file 6.

Another feature of this study is to demonstrate associations between air pollutants and the clinical pathogenic microorganism inspection results in the cases of hospitalization due to pneumonia among Guangzhou children. The clinical pathogenic microorganism inspection results for pneumonia are shown in additional file 7. The detected cases of pulmonary Mycoplasma pneumoniae were the most predominant, accounting for $37.28 \%$ of total detected cases of microorganism inspection (TDCMI). The positive rate was the largest in the age group 1-5 years. The positive rate minimized in winter for all kinds of pathogenic microorganisms, except that for Chlamydia pneumoniae and Hemophilus. The Lasso regression model was derived for the daily cases of microbial detection due to pneumonia and air pollutants (lag 0-6), combined with meteorological factors. $\mathrm{RCs}$ of daily mean $\mathrm{NO}_{2}$ levels were always positive which indicated that $\mathrm{NO}_{2}$ had significantly positive effects on the daily cases of microbial detection for pneumonia. RCs of daily mean $\mathrm{O}_{3}$ levels were almost positive except for Flu B virus, Chlamydia pneumonia and Adenovirus. While RCs of daily mean $\mathrm{SO}_{2}$ levels were almost negative, except for Adenovirus, which indicated that daily mean $\mathrm{SO}_{2}$ levels had negative effects on the daily cases of microbial detection. We find out that RCs of daily mean $\mathrm{PM}_{10}$ levels were positive for Mycoplasma pneumonia, Parainfluenza virus and Haemophilus, which accounting for $37.27 \%$, $6.65 \%$ and $1.62 \%$ of TDCMI in children aged $0-17$, respectively; the detected cases of these three kinds of pathogenic microorganisms accounted for $45.56 \%$ of TDCMI in whole children population. RCs of daily mean $\mathrm{PM}_{2.5}$ levels were both positive for Flu $A$ virus which accounting for $4.61 \%$ only in infants and $15.64 \%$ among the $1-5$ year age group, and Flu $B$ virus which accounting for $10.68 \%$ only in infants and $32.60 \%$ among the $1-5$ year age group; the detected cases of these two kind of pathogenic microorganisms accounted for $25.74 \%$. RCs of daily mean $\mathrm{PM}_{10}, \mathrm{NO}_{2}, \mathrm{CO}_{\text {and }} \mathrm{O}_{3}$ levels were positive to Mycoplasdema pneumonia which accounting for $24.89 \%$ in infants and $63.36 \%$ among the $1-5$ year age group simultaneously. RCs of daily mean $\mathrm{PM}_{2.5}$ and $\mathrm{NO}_{2}$ levels were positive to Influenza $A$ and $\mathrm{B}$ virus simultaneously. $\mathrm{RCs}$ of daily mean $\mathrm{O}_{3}, \mathrm{PM}_{2.5}$ and $\mathrm{PM}_{10}$ levels were mainly positive for children less than 5 years-old. RCs of daily mean $\mathrm{SO}_{2}, \mathrm{NO}_{2}$ and $\mathrm{CO}$ levels were mainly positive for children aged 6-17 years. The pneumonia hospitalizations due to Mycoplasma pneumonia, Flu A virus and Flu B virus in children aged 0-5 are apparently associated with the levels of air pollutants (i.e. $\mathrm{PMs}_{2} \mathrm{NO}_{2}, \mathrm{CO}$ and $\mathrm{O}_{3}$ ). And pathogenic microorganisms, such as Mycoplasma pneumonia, Flu $A$ virus and Flu $B$ virus, might be possibly carried by PMs, which increased risks of the acute lower respiratory infections in children aged 0-5 years. We fortunately found a study from Urumqi city of Western China, which reported that the microorganisms responsible for human allergy and respiratory disease carried by $\mathrm{PM}_{10}$ and $\mathrm{PM}_{1}$ had been analyzed during winter. Their results showed that the bacterial community was mainly composed of Proteobacteria, Firmicutes and Actinobacteria. The sequences of several pathogenic bacteria and opportunistic pathogens were also detected, such as Acinetobacter, Delftia, Serratia, Chryseobacterium, which might impact on immunocompromised populations (elderly, children and postoperative convalescence patients) ${ }^{[35]}$. However, to our knowledge, no previous study has studied the association between outdoor air pollutants and daily cases of microbial detection for pneumonia in children.

Nowadays, further investigations are warranted. 
This study has some limitations. The GDMCHH is the tertiary hospital, children with severe diseases might make up a larger proportion than in other hospitals. No doubt, outpatients were excluded from our study. Therefore, to obtain a more convincing explanation of the effects of air pollutants among children aged 6-17 years, the data from other local tertiary hospitals would be used to analyze. The effect estimates in our model are based on the sample size. If our sample size was large enough, the conclusions should be more accurate.

\section{Conclusion}

In summary, we have found the positive associations between children's hospital admissions for lower respiratory infections and air pollutants as well as associations between air pollutants and the clinical pathogenic microorganism inspection results in the cases of hospitalization due to pneumonia among Guangzhou children. Significant associations were found for air pollutants except for $\mathrm{PM}_{10}$ in children aged 0-17 years. Our study suggested that short-term exposures to air pollutions, especially to $\mathrm{CO}$ and $\mathrm{NO}_{2}$, were associated with increased risk of hospital admissions for pneumonia of children under 17 years old. The pneumonia hospitalizations due to Mycoplasma pneumonia, Flu A virus and Flu B virus, the predominant pathogenic microorganisms detected in children aged 0-5 are apparently associated with levels of smaller size particulate matters, carbon monoxide, nitrogen dioxide and ozone. We suggest the Guangzhou Municipal Government should make more efforts to improve the local air quality.

\section{Abbreviations}

ARI: Acute Respiratory Infection

Cl: Confidence Interval

ED: Emergency Department

RTI: Respiratory Tract Infection

RR: Risk Ratio

AQI: Air Quality Index

GDMCHH: Guangdong Maternal and Child Healthcare Hospital

DOW: Day of the Week

IQR: Interquartile Range

VIF: Variance Inflation Factor

RMSE: Root Mean-Square Error

RCs: Regression Coefficients

WHO: World Health Organization

TDCMI: Total Detected Cases of Microorganism Inspection

\section{Declarations}

\section{Authors' contributions}

M. H. conceived the idea of the study, designed the study. HW Z., LL Y., W Q., ZY X., LT W. and JM J. collected and analyzed the data. All authors discussed the results, revised the manuscript and approved the final manuscript.

\section{Additional information}

\section{Ethics approval and consent to participate}

The study obtained ethical approval from the ethical committee of the Guangdong Maternal and Child Healthcare Hospital (Approval number: 201901121, September 2019).

\section{Availability of data and materials}

The datasets of ambient air quality data and meteorological data supporting the conclusions of this article are available in the Guangzhou Municipal Air Quality Real-time [http://210.72.1.33:8023/gzaqi_new/RealTimeDate.html] and Reliable Prognosis website [http://rp5.ru/docs/about/cn] 
The datasets of daily hospitalized records analyzed during the current study are not publicly available due their containing information that could compromise the privacy of research participants but are available from the corresponding author on reasonable request.

\section{Competing interests}

The authors declare that they have no competing interests.

\section{Funding}

This work was supported by the National Natural Science Foundation of China (No. 31870348).

\section{References}

1. Saux Le, N. \& Jl, R. Pneumonia in healthy Canadian children and youth: Practice points for management. Child Health16, 417 (2011).

2. Nguyen, T. K. P., Tran, T. H., Roberts, C. L., Graham, S. M. \& Marais, B. J. Child pneumonia - focus on the Western Pacific Region. Respir. Rev.21, 102110 (2017).

3. Lima, E. J. D. F. et al. Risk factors for community-acquired pneumonia in children under five years of age in the post-pneumococcal conjugate vaccine era in Brazil: a case control study. Bmc Pediatr.16, 157 (2016).

4. Reynolds, J. H., Mcdonald ., G., Alton ., H. \& Gordon, S. B. Pneumonia in the immunocompetent patient. Br J Radio/83, 998-1009 (2010).

5. Barnett, A. G. et al. Air pollution and child respiratory health: A case-crossover study in Australia and New Zealand. J. Respir. Crit. Care Med.171, 1272-1278 (2005).

6. Darrow, L. A. et al. Air pollution and acute respiratory infections among children 0-4 years of age: An 18-year time-series study. J. Epidemiol.180, 968-977 (2014).

7. Qiu, H. et al. Coarse particulate matter associated with increased risk of emergency hospital admissions for pneumonia in Hong Kong. Thorax69, 1027-1033 (2014).

8. Winquist, A. et al. Comparison of emergency department and hospital admissions data for air pollution time-series studies. Heal. A Glob. Access Sci. Source11, (2012).

9. GURJAR et al. Human health risks in megacities due to air pollution. Environ.44, 4606-4613 (2010).

10. Mehta, S. et al. Air pollution and admissions for acute lower respiratory infections in young children of Ho Chi Minh City. Air Qual. Atmos. Heal.6, 167-179 (2013).

11. Nhung, N. T. T., Schindler, C., Dien, T. M., Probst-Hensch, N. \& Künzli, N. Association of ambient air pollution with lengths of hospital stay for hanoi children with acute lower-respiratory infection, 2007-2016. Pollut.247, 752-762 (2019).

12. Nathan, A. M. et al. Clinical risk factors for life-threatening lower respiratory tract infections in children: A retrospective study in an urban city in Malaysia. PLoS One9, 1-8 (2014).

13. Li, H. et al. Short-term effects of various ozone metrics on cardiopulmonary function in chronic obstructive pulmonary disease patients: Results from a panel study in Beijing, China. Pollut.232, 358 (2017).

14. Chen, B., Hong, C. \& Kan, H. Exposures and health outcomes from outdoor air pollutants in China. Toxicology198, 291-300 (2004).

15. Yuyu, C., Avraham, E., Michael, G. \& Hongbin, L. Evidence on the impact of sustained exposure to air pollution on life expectancy from China's Huai River policy. PNAS110, 12936-12941 (2013).

16. Wang, Y. et al. Associations of daily mortality with short-term exposure to PM2.5 and its constituents in Shanghai, China. Chemosphere233, $879-$ 887 (2019).

17. Liu, J. et al. Association between ambient PM2.5 and children's hospital admissions for respiratory diseases in Jinan, China. Sci. Pollut. Res. 24112-24120 (2019). doi:10.1007/s11356-019-05644-7

18. Ge, E. et al. Differential effects of size-specific particulate matter on emergency department visits for respiratory and cardiovascular diseases in Guangzhou, China. Pollut.243, 336-345 (2018).

19. Mokoena, K. K., Ethan, C. J., Yu, Y., Shale, K. \& Liu, F. Ambient air pollution and respiratory mortality in Xi'an, China: a time-series analysis. Res.20, 19 (2019).

20. Qian, Z. et al. Effects of Air Pollution on Children's Respiratory Health in Three Chinese Cities. Environ. Health55, 126-133 (2000).

21. Guangzhou statistics bureau. Available at: http://tjj.gz.gov.cn/.

22. National Bureau of Statistics of China. Available at: http://www.stats.gov.cn/tjsj./ndsj/.

23. Ostro, B., Roth, L., Malig, B. \& Marty, M. The effects of fine particle components on respiratory hospital admissions in children. Health Perspect.117, 475-480 (2009).

24. T W, W. et al. Air pollution and hospital admissions for respiratory and cardiovascular diseases in Hong Kong. Environ. Med.56, 679-683 (1999).

25. Minh, C., Hcmc, C. \& Ascertainment, C. The effects of short-term exposure on hospital admissions for acute lower respiratory infections in young children of Ho Chi Minh City Collaborative Working Group on Air Pollution , Poverty , and Health. 8-11 (2005). 
26. Bhaskaran, K., Gasparrini, A., Hajat, S., Smeeth, L. \& Armstrong, B. Time series regression studies in environmental epidemiology. 7, 1187-1195 (2013).

27. Poovendhree, R. et al. GSTM1 and GSTP1 gene variants and the effect of air pollutants on lung function measures in South African children. J. Ind. Med.55, 1078 (2012).

28. Jr, P. R. et al. Reduced gene expression levels after chronic exposure to high concentrations of air pollutants. Res. Mol. Mech. Mutagen.780, 60-70 (2015).

29. Jung, E. M. et al.. Association between prenatal exposure to PM2.5 and the increased risk of specified infant mortality in South Korea. Environment Internationa/144, 105997 (2020).

30. Zwozdziak, A. et al. Influence of PM1 and PM2.5 on lung function parameters in healthy schoolchildren-a panel study. Sci. Pollut. Res.23, 2389223901 (2016).

31. Frampton, M. W. \& Rich, D. Q. Does particle size matter? ultrafine particles and hospital visits in eastern Europe. J. Respir. Crit. Care Med.194, 11801182 (2016).

32. Oberdorster, G., Ferin, J. \& Lehnert, B. E. Correlation between particle size, in vivo particle persistence, and lung injury. Health Perspect.102, 173-179 (1994).

33. Ntt, N. et al. Acute effects of ambient air pollution on lower respiratory infections in Hanoi children: An eight-year time series study. Int.110, 139 (2018).

34. Yorifuji, T., Kashima, S. \& Doi, H. Acute exposure to fine and coarse particulate matter and infant mortality in Tokyo, Japan (2002-2013). Science of The Total Environment551-552, 66-72 (2016).

35. Gou, H. et al. Assessment of microbial communities in PM 1 and PM 10 of Urumqi during winter. Pollut.214, 202-210 (2016).

36. Guangzhou Municipal Air Quality Real-time Release Platform. Available at: http://210.72.1.33:8023/gzaqi_new/RealTimeDate.html. (Accessed: 1st October 2019)

37. Reliable Prognosis. Available at: https://rp5.ru/docs/about/cn. (Accessed: 1st October 2019)

38. Kutner MH. Applied linear statistical models. 5th ed. McGraw-Hill; Irwin. 2005.

\section{Tables}

Table 1. Descriptive statistics for daily pneumonia hospital admissions and detected results of sputum cultivation in Guangzhou, $2013-2018$ 


\begin{tabular}{|c|c|c|c|c|c|c|}
\hline Group & $\begin{array}{l}\text { Number of } \\
\text { admissions }\end{array}$ & $\begin{array}{l}\text { Daily mean } \\
\text { (SD) }\end{array}$ & $\begin{array}{l}\text { Daily mean in } \\
\text { spring (SD) } \\
\text { (March-May) }\end{array}$ & $\begin{array}{l}\text { Daily mean in } \\
\text { summer (SD) } \\
\text { (July-August) }\end{array}$ & $\begin{array}{l}\text { Daily mean in fall } \\
\text { (SD) } \\
\text { (September- } \\
\text { November) }\end{array}$ & $\begin{array}{l}\text { Daily mean in } \\
\text { winter (SD) } \\
\text { (December- } \\
\text { February) }\end{array}$ \\
\hline \multicolumn{7}{|l|}{ By gender } \\
\hline Boy & 10973 & $6.43(5.10)$ & $7.68(5.54)$ & $5.98(4.33)$ & $5.72(4.96)$ & $6.17(5.18)$ \\
\hline Girl & 6176 & $3.62(3.13)$ & 4.37(3.39) & $3.14(2.59)$ & $3.38(3.14)$ & $3.49(3.14)$ \\
\hline \multicolumn{7}{|l|}{ By age } \\
\hline$<1$ year & 11543 & $6.76(5.34)$ & $8.47(5.93)$ & $6.21(4.29)$ & $5.83(5.24)$ & $6.33(5.26)$ \\
\hline $1-5$ years & 4743 & $2.78(2.59)$ & $3.13(2.75)$ & $2.38(2.21)$ & $2.84(2.72)$ & $2.71(2.57)$ \\
\hline $6-17$ years & 863 & $0.51(0.87)$ & $0.45(0.79)$ & $0.53(0.91)$ & $0.43(0.74)$ & $0.61(1.01)$ \\
\hline All age $0-17$ & 17149 & $10.10(7.60)$ & $12.10(8.31)$ & $9.12(6.18)$ & $9.10(7.52)$ & $9.66(7.71)$ \\
\hline \multicolumn{7}{|l|}{ Microbe } \\
\hline $\begin{array}{l}\text { Chlamydia } \\
\text { pneumoniae }\end{array}$ & 104 & $0.06(0.29)$ & $0.08(0.32)$ & $0.07(0.33)$ & $0.04(0.21)$ & $0.06(0.27)$ \\
\hline Haemophilus & 278 & $0.16(0.56)$ & $0.30(0.80)$ & $0.09(0.36)$ & $0.08(0.32)$ & $0.16(0.56)$ \\
\hline $\begin{array}{l}\text { Mycoplasma } \\
\text { pneumoniae }\end{array}$ & 6393 & $3.75(3.64)$ & $4.74(4.41)$ & $3.59(3.16)$ & $3.57(3.41)$ & $3.02(3.13)$ \\
\hline Influenza A virus & 1397 & $0.81(1.88)$ & $0.95(1.93)$ & $0.84(1.76)$ & $0.86(2.17)$ & $0.63(1.66)$ \\
\hline Influenza B virus & 3018 & $1.77(2.63)$ & $2.66(2.89)$ & $1.77(2.45)$ & $1.36(2.61)$ & $1.21(2.25)$ \\
\hline Parainfluenza virus & 1142 & $0.67(1.43)$ & $0.93(1.62)$ & $0.57(1.40)$ & $0.59(1.36)$ & $0.56(1.27)$ \\
\hline Adenovirus & 627 & $0.37(0.83)$ & $0.56(0.98)$ & $0.41(0.90)$ & $0.28(0.78)$ & $0.22(0.54)$ \\
\hline $\begin{array}{l}\text { Respiratory } \\
\text { syncytial virus }\end{array}$ & 1042 & $0.61(1.27)$ & $0.72(1.24)$ & $0.66(1.34)$ & $0.66(1.55)$ & $0.42(0.89)$ \\
\hline
\end{tabular}

Table 2. Overall and seasonal distribution of daily pollutant concentrations, Guangzhou, 2013-2018 


\begin{tabular}{|c|c|c|c|c|c|c|c|c|}
\hline Variable & $\begin{array}{l}\text { Daily mean } \\
\text { (SD) }\end{array}$ & Median & $\begin{array}{l}\text { Minimum- } \\
\text { maximum }\end{array}$ & $\begin{array}{l}\text { Interquartile } \\
\text { range }\end{array}$ & $\begin{array}{l}\text { Daily mean in } \\
\text { spring (SD) } \\
\text { (March-May) }\end{array}$ & $\begin{array}{l}\text { Daily mean in } \\
\text { summer (SD) } \\
\text { (July-August) }\end{array}$ & $\begin{array}{l}\text { Daily mean in } \\
\text { fall (SD) } \\
\text { (September- } \\
\text { November) }\end{array}$ & $\begin{array}{l}\text { Daily mean in } \\
\text { winter (SD) } \\
\text { (December- } \\
\text { February) }\end{array}$ \\
\hline \multicolumn{9}{|c|}{ Pollutants $\left(\mu \mathrm{g} / \mathrm{m}^{3}\right)$} \\
\hline 24h $\mathrm{PM}_{2.5}$ & $39.80(22.90)$ & 34.00 & $\begin{array}{l}4.61- \\
155.00\end{array}$ & 27.20 & $37.00(17.60)$ & $26.80(12.90)$ & $40.70(19.00)$ & $53.10(29.50)$ \\
\hline 24h $\mathrm{PM}_{10}$ & $60.80(30.10)$ & 53.00 & $\begin{array}{l}9.96- \\
208.00\end{array}$ & 37.30 & $58.00(24.60)$ & $44.50(16.60)$ & $64.00(27.50)$ & $75.30(38.10)$ \\
\hline $24 \mathrm{~h} \mathrm{SO}_{2}$ & $12.90(5.89)$ & 11.50 & $2.00-53.00$ & 6.50 & $12.60(4.91)$ & $11.60(3.98)$ & $13.00(5.38)$ & $14.30(7.97)$ \\
\hline $24 \mathrm{~h} \mathrm{NO}_{2}$ & $37.30(25.70)$ & 37.60 & $\begin{array}{l}0.55- \\
163.00\end{array}$ & 28.40 & $40.80(24.30)$ & $27.70(16.90)$ & $34.80(23.90)$ & $44.60(31.60)$ \\
\hline 24h CO & $935.00(238.00)$ & 890.00 & $\begin{array}{l}479.00- \\
2610.00\end{array}$ & 279.00 & $922.00(218.00)$ & $788.00(128.00)$ & $934.00(153.00)$ & $1080.00(303.00)$ \\
\hline $8 \mathrm{~h} \mathrm{O}_{3}$ & $46.90(25.20)$ & 43.60 & $\begin{array}{l}3.46- \\
139.00\end{array}$ & 35.80 & $43.10(26.10)$ & $52.20(25.40)$ & $52.60(27.00)$ & $41.00(19.80)$ \\
\hline \multicolumn{9}{|c|}{ Meteorological factors } \\
\hline $\begin{array}{l}\text { Temperature } \\
\left({ }^{\circ} \mathrm{C}\right)\end{array}$ & $21.70(6.27)$ & 23.10 & $3.46-31.40$ & 23.70 & $21.90(4.57)$ & $28.20(1.70)$ & $23.50(4.17)$ & $14.20(3.73)$ \\
\hline $\begin{array}{l}\text { Pressure } \\
(\mathrm{mm} / \mathrm{Hg})\end{array}$ & $758.00(24.70)$ & 760.00 & $\begin{array}{l}380.00- \\
778.00\end{array}$ & 8.10 & $754.00(40.90)$ & $753.00(17.21)$ & $760.00(12.30)$ & $765.00(11.30)$ \\
\hline $\begin{array}{l}\text { Relative } \\
\text { Humidity } \\
(\%)\end{array}$ & 77.90(11.20) & 79.10 & $\begin{array}{l}29.60- \\
99.80\end{array}$ & 13.50 & $81.80(9.73)$ & $81.40(7.75)$ & 77.10(9.67) & $71.70(13.30)$ \\
\hline $\begin{array}{l}\text { Wind speed } \\
(\mathrm{m} / \mathrm{s})\end{array}$ & $2.31(0.95)$ & 2.13 & $0.50-6.75$ & 1.25 & $2.19(0.83)$ & $2.05(0.76)$ & $2.27(0.95)$ & $2.68(1.09)$ \\
\hline $\begin{array}{l}\text { Horizontal } \\
\text { visibility } \\
(\mathrm{km})\end{array}$ & $12.60(5.93)$ & 11.70 & $0.68-30.00$ & 8.05 & $11.10(5.93)$ & $15.00(5.79)$ & $12.40(5.56)$ & $12.10(5.75)$ \\
\hline $\begin{array}{l}\text { Precipitation } \\
(\mathrm{mm})\end{array}$ & $6.70(18.00)$ & 0.00 & $\begin{array}{l}0.00- \\
222.00\end{array}$ & 4.10 & $9.10(21.90)$ & $12.30(23.80)$ & $3.16(9.48)$ & $2.40(9.63)$ \\
\hline
\end{tabular}

Table 3. RR for an IQR increase in the 7-day moving average (lag 0-6) of ambient air pollution concentrations and children pneumonia hospital admissions

Daily hospital admissions and interquartile range units presented in Table 2. Risk ratios (RR) estimated from Quasi-Poisson regression models, adjusting for secular trends and seasonal variation, day of the week, holiday, influenza epidemic, and meteorological factors including temperature, relative humidity, pressure, horizontal visibility, precipitation and wind speed average. ${ }^{\star} p<0.05$. ${ }^{\star \star} p<0.01$ (Wald $\chi^{2}$ test).

\begin{tabular}{|c|c|c|c|c|c|c|c|c|c|c|c|c|}
\hline \multirow[t]{3}{*}{ Outcome by pollutant } & \multicolumn{3}{|c|}{ All ages (0-17) } & \multicolumn{3}{|c|}{$<1$ Years of age } & \multicolumn{3}{|c|}{ 1-5 Years old } & \multicolumn{3}{|c|}{ 6-17 Years old } \\
\hline & \multirow[t]{2}{*}{ RR } & \multicolumn{2}{|l|}{$95 \% \mathrm{Cl}$} & \multirow[t]{2}{*}{ RR } & \multicolumn{2}{|l|}{$95 \% \mathrm{Cl}$} & \multirow[t]{2}{*}{ RR } & \multicolumn{2}{|l|}{$95 \% \mathrm{Cl}$} & \multirow[t]{2}{*}{ RR } & \multicolumn{2}{|l|}{$95 \% \mathrm{Cl}$} \\
\hline & & Lower & Upper & & Lower & Upper & & Lower & Upper & & Lower & Upper \\
\hline $\mathrm{PM}_{2.5}$ & 0.95 & 0.87 & 1.03 & $0.90^{*}$ & 0.82 & 0.99 & 1.07 & 0.97 & 1.18 & 1.11 & 0.90 & 1.37 \\
\hline $\mathrm{PM}_{10}$ & 0.97 & 0.90 & 1.05 & 0.93 & 0.86 & 1.02 & 1.06 & 0.97 & 1.17 & 1.09 & 0.90 & 1.35 \\
\hline $\mathrm{SO}_{2}$ & 1.00 & 0.94 & 1.07 & 0.98 & 0.91 & 1.05 & 1.03 & 0.94 & 1.13 & $1.21^{\star}$ & 1.02 & 1.45 \\
\hline $\mathrm{NO}_{2}$ & 1.06 & 0.98 & 1.14 & 1.03 & 0.95 & 1.12 & 1.06 & 0.95 & 1.18 & $1.25^{\star}$ & 1.01 & 1.56 \\
\hline $\mathrm{CO}$ & 1.02 & 0.94 & 1.11 & 0.97 & 0.89 & 1.05 & $1.15^{\star \star}$ & 1.04 & 1.27 & $1.26^{\star}$ & 1.01 & 1.57 \\
\hline $\mathrm{O}_{3}$ & 0.98 & 0.91 & 1.06 & 1.01 & 0.93 & 1.10 & 0.94 & 0.85 & 1.04 & $0.81^{*}$ & 0.66 & 1.00 \\
\hline
\end{tabular}

Table 4. Regression coefficients of the 7-day moving average ambient air pollutants in Lasso regression models with cases of pneumonia microbial detection 


\begin{tabular}{|llllllll|}
\hline & $\mathrm{PM}_{2.5}$ & $\mathrm{PM}_{10}$ & $\mathrm{SO}_{2}$ & $\mathrm{NO}_{2}$ & $\mathrm{CO}$ & $\mathrm{O}_{3}$ & $\mathrm{RMSE}$ \\
\hline Chlamydia pneumoniae & $-1.46 \times 10^{-2}$ & 0 & $-1.47 \times 10^{-1}$ & $4.00 \times 10^{-2}$ & $-1.20 \times 10^{-3}$ & 0 & 0.28 \\
\hline Haemophilus & $-4.36 \times 10^{-2}$ & $8.40 \times 10^{-3}$ & $-1.19 \times 10^{-1}$ & $1.48 \times 10^{-2}$ & $3.32 \times 10^{-3}$ & $9.50 \times 10^{-3}$ & 0.51 \\
\hline Mycoplasma pneumoniae & $-3.48 \times 10^{-2}$ & $2.00 \times 10^{-2}$ & $-3.15 \times 10^{-2}$ & $8.50 \times 10^{-3}$ & $7.00 \times 10^{-4}$ & $4.00 \times 10^{-4}$ & 2.85 \\
\hline Influenza A virus & $2.67 \times 10^{-2}$ & $-9.50 \times 10^{-3}$ & $-2.31 \times 10^{-1}$ & $7.15 \times 10^{-2}$ & $-5.91 \times 10^{-3}$ & $4.80 \times 10^{-3}$ & 1.50 \\
\hline Influenza B virus & $3.69 \times 10^{-2}$ & $-2.36 \times 10^{-2}$ & $-2.87 \times 10^{-2}$ & $2.17 \times 10^{-2}$ & $-2.32 \times 10^{-3}$ & $-7.00 \times 10^{-4}$ & 2.17 \\
\hline Parainfluenza virus & $-6.74 \times 10^{-2}$ & $2.01 \times 10^{-2}$ & $-8.15 \times 10^{-2}$ & $4.10 \times 10^{-2}$ & $1.31 \times 10^{-3}$ & $3.90 \times 10^{-3}$ & 1.29 \\
\hline Adenovirus & $-2.30 \times 10^{-2}$ & $-5.70 \times 10^{-3}$ & 0 & $3.16 \times 10^{-2}$ & 0 & 0 & 0.76 \\
\hline Respiratory syncytial virus & $-1.20 \times 10^{-2}$ & $-6.10 \times 10^{-3}$ & $-1.80 \times 10^{-1}$ & $5.59 \times 10^{-2}$ & $-1.71 \times 10^{-3}$ & $1.16 \times 10^{-2}$ & 1.07 \\
\hline
\end{tabular}

\section{Figures}
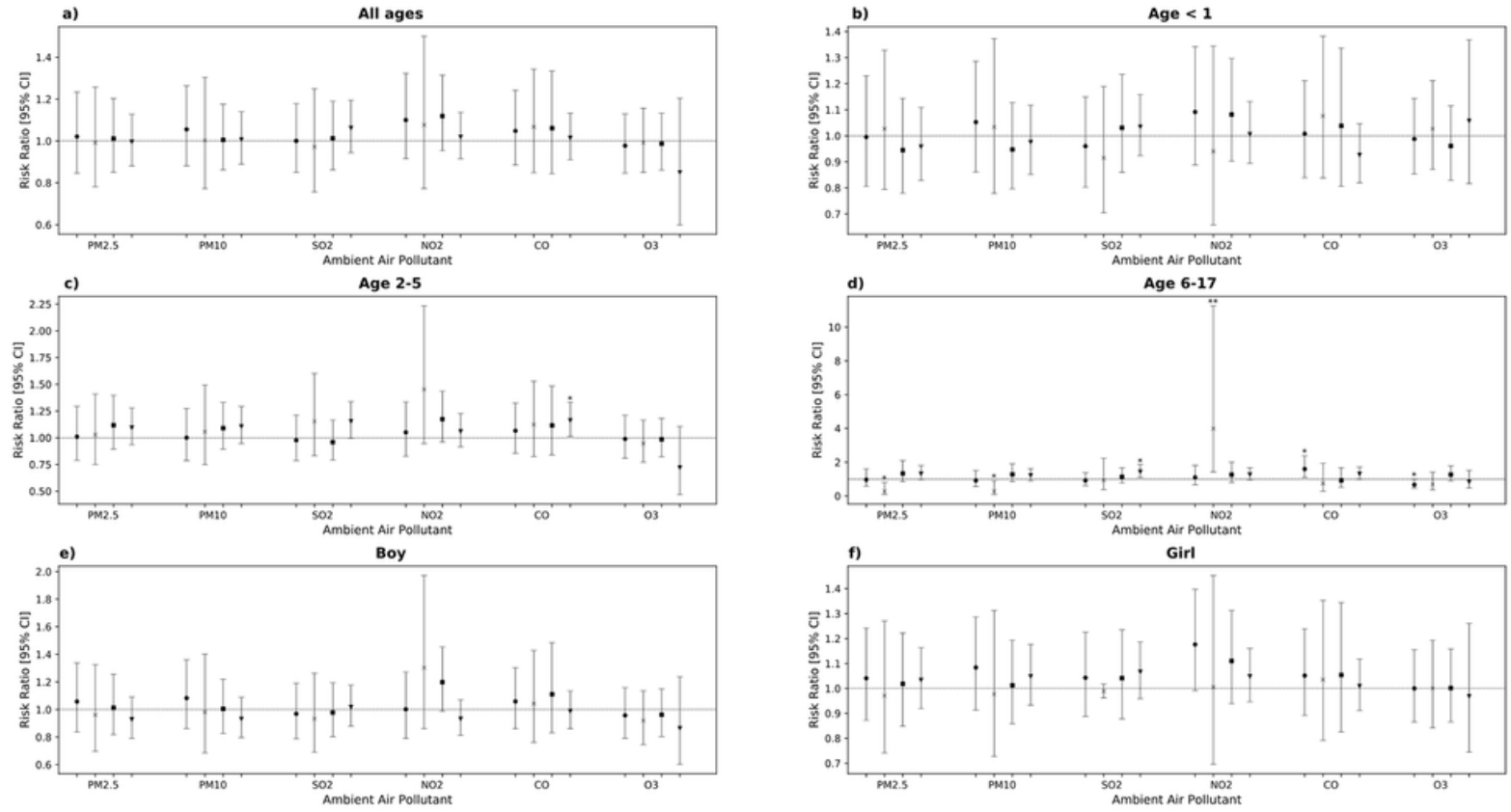

Figure 1

Season-specific RR per IQR increment in the seven-day moving average (lag 0-6) ambient air pollutant concentrations for a) all ages, b) infants, c) age 15, d) age 6-17, e) boys, f) girls, in Guangzhou. Circle dot: Spring (March-May), cross symbol: Summer (June-August), square: Fall (September-November), triangle point down: Winter (December-February). Bar: $95 \%$ confidence intervals, ${ }^{*} p<0.05 .{ }^{* *} p<0.01$. 

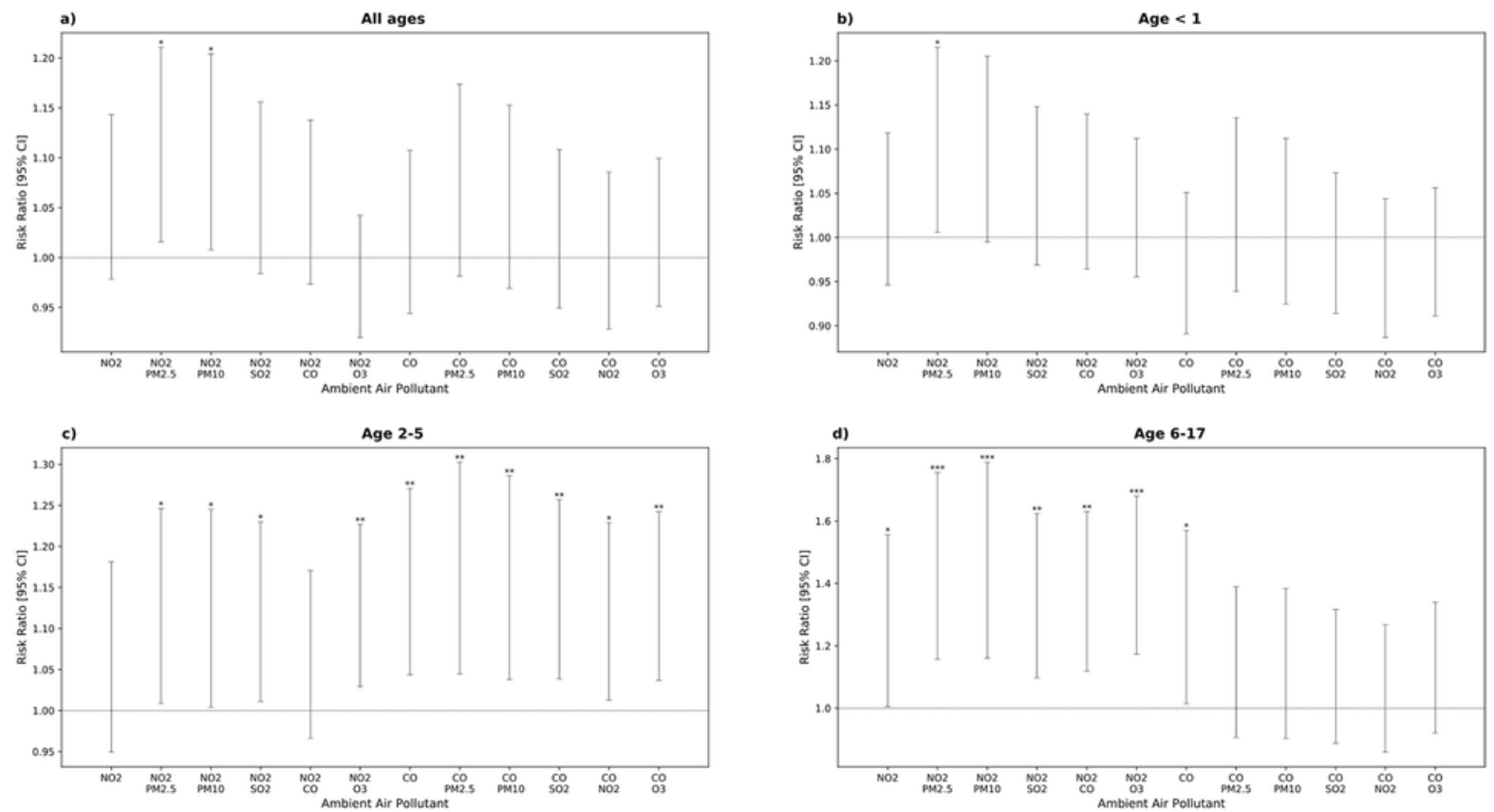

\section{Figure 2}

RR per IQR increment of NO2 and CO respectively, from single pollutants models (left most estimated) and two pollutant models with adjustment for PM2.5, PM10, SO2, NO2, CO and 03, for a) all ages, b) age < 1, c) age 1-5, d) age 6-17, Guangzhou. Bar: $95 \%$ confidence intervals, *p < $0.05 .{ }^{\star \star}$ p < 0.01. $\star \star * p<0.001$.
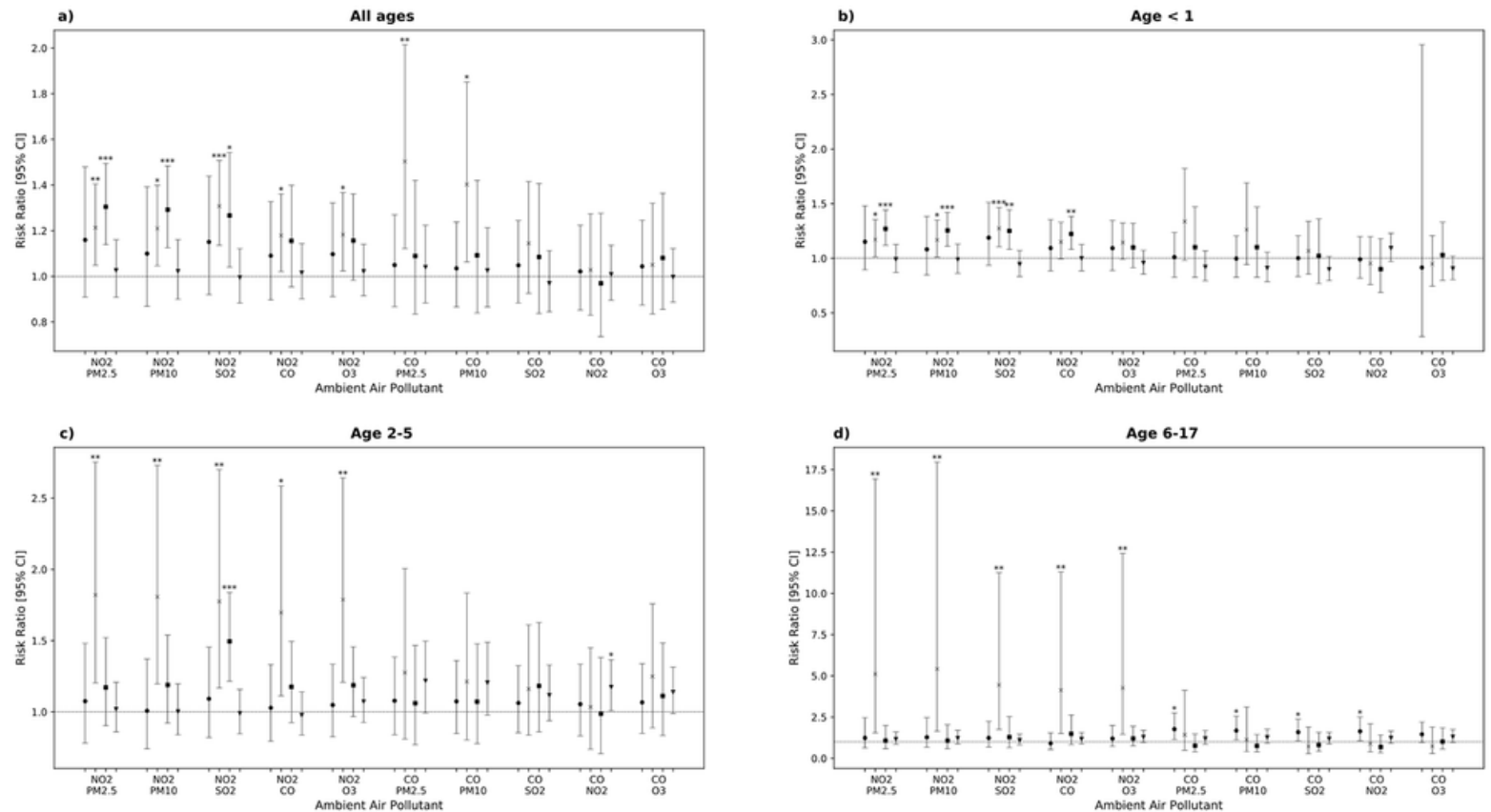

\section{Figure 3}

Season-specific estimated RR per IQR increment of NO2 and CO respectively, two pollutant models with adjustment for PM2.5, PM10, SO2, NO2, CO and 03, for a) all ages, b) age < 1, c) age 1-5, d) age 6-17, Guangzhou. Circle dot: Spring (March-May), cross symbol: Summer (June-August), square: Fall (September-November), triangle point down: Winter (December-February). Bar: 95\% confidence intervals, ${ }^{*} p<0.05 .{ }^{* \star} p<0.01$. ${ }^{\star * \star} p<0.001$. 


\section{Supplementary Files}

This is a list of supplementary files associated with this preprint. Click to download.

- Additionalfile1.docx

- Additionalfile10.docx

- Additionalfile2.docx

- Additionalfile3.docx

- Additionalfile4.docx

- Additionalfile5.docx

- Additionalfile6.docx

- Additionalfile7.docx

- Additionalfile8.docx

- Additionalfile9.docx 